\title{
Spatial and Temporal Distribution of Geminiviruses in Leafhoppers of the Genus Cicadulina Monitored by Conventional and Quantitative Polymerase Chain Reaction
}

\author{
Jean-Michel Lett, Martine Granier, Isabelle Hippolyte, Martial Grondin, Monique Royer, \\ Stéphane Blanc, Bernard Reynaud, and Michel Peterschmitt
}

\begin{abstract}
First, second, and eighth authors: CIRAD-AMIS, Laboratoire de Virologie, TA 40/02, 34398 Montpellier Cedex 5, France; third author: CIRAD-AMIS, Laboratoire BIOTROP-ALBHADES, TA 40/03, 34398 Montpellier Cedex 5, France; fourth and seventh authors: CIRADAMIS, Pôle de Protection des Plantes, 97410 Saint-Pierre, La Réunion, France; fifth author: CIRAD-AMIS, Laboratoire IGEPAM, TA 40/02, 34398 Montpellier Cedex 5, France; and sixth author: INRA-CNRS, Laboratoire de biologie cellulaire et moléculaire, 30380 SaintChristol les Alès, France.
\end{abstract}

Accepted for publication 10 September 2001.

\section{ABSTRACT}

Lett, J.-M., Granier, M., Hippolyte, I., Grondin, M., Royer, M., Blanc, S., Reynaud, B., and Peterschmitt, M. 2002. Spatial and temporal distribution of geminiviruses in leafhoppers of the genus Cicadulina monitored by conventional and quantitative polymerase chain reaction. Phytopathology 92:65-74.

Spatial and temporal distribution of Maize streak virus (MSV, family Geminiviridae, genus Mastrevirus) was monitored in the vector species Cicadulina mbila and the nonvector species C. chinaï using conventional and real-time quantitative polymerase chain reaction. Sustained feeding on MSV-infected plants showed that virus accumulation reaches a maxi- mum in C. chinaï, but not in $C$. mbila. After a 3-day acquisition access feeding period (AAP), MSV was detected in the gut, the hemolymph, and the head of C. mbila, but only in the gut of $C$. chinaï. Similarly, Digitaria streak virus (genus Mastrevirus), which is not transmitted by either of the two species, was only detected in the gut. MSV was detected in the hemolymph of $C$. mbila $3 \mathrm{~h}$ after the beginning of the AAP. Although viral DNA progressively decreases in the vector and nonvector species after a 3-day AAP, MSV DNA remained stable in the salivary glands of C. mbila.

Additional keywords: circulative transmission, insect compartments, transmission barrier, viral kinetics.
Viruses of the family Geminiviridae are classified as plant viruses transmitted by piercing-sucking insects in a circulative nonpropagative manner (15). It is supposed that the receptor-mediated endocytosis mechanisms demonstrated for viruses in the family Luteoviridae $(12,13)$ are involved in insect transmission of geminiviruses, because both families contain circulative nonpropagated viruses (14). However, there are numerous differences between viruses belonging to these two families, and results obtained for one cannot be directly extrapolated to the other.

Viruses in the family Luteoviridae are transmitted by aphids, whereas in the family Geminiviridae, viruses in the genera Mastrevirus and Curtovirus are transmitted by leafhoppers (Cicadellidae), those in the genus Begomovirus by whiteflies (Aleyrodidae), and Tomato pseudocurly top virus in the genus Topocuvirus by a treehopper (Membracidae). Whereas virus replication in the insect vector has never been suggested in the family Luteoviridae, the situation is less clear for geminiviruses. In spite of several studies that did not show an increase of the amount of virus in vectors that had fed on plants infected by geminiviruses $(4,31)$, it has been suggested that Tomato yellow leaf curl virus (TYLCV), a member of the genus Begomovirus, may replicate in its vector, Bemisia tabaci $(22,23)$. Thus, the mechanism of the transmission of geminiviruses may be more complex than that of viruses of the

Corresponding author: M. Peterschmitt

E-mail address: michel.peterschmitt@cirad.fr

Publication no. P-2001-1026-01R

(C) 2002 The American Phytopathological Society family Luteoviridae. This was further demonstrated through (i) the transovarial and sexual transmission of an Israeli isolate of TYLCV by B. tabaci $(9,11)$, (ii) the presence of Squash leaf curl virus (SLCV), a member of the genus Begomovirus, in different types of whitefly tissues exhibiting cytopathologic changes (16, 26), and (iii) the negative impact of TYLCV on the biology and reproduction of $B$. tabaci (33).

The aim of this study was to increase our knowledge of the circulative nonpropagative transmission of a geminivirus in the genus Mastrevirus, Maize streak virus (MSV). MSV is transmitted by 8 out of 22 species of leafhoppers belonging to the genus Cicadulina (40). Similar to viruses in the family Luteoviridae and in begomoviruses, there was no increase of the virus amount in the insects after an acquisition access feeding period (AAP) on infected plants, which is consistent with nonpropagative transmission $(3,31)$. Moreover, the transmission of MSV by a nonvector species belonging to the genus Cicadulina occurred after injection of the virus into the hemolymph, showing that the gut wall acts as a barrier to transmission $(21,30,36)$. In this report, we use a novel procedure based on polymerase chain reaction (PCR) to investigate the relationship between MSV and its insect vector. We were able to (i) demonstrate a differential virus persistence and accumulation between vector and nonvector leafhopper species, (ii) show that the gut wall acts as a physical barrier for viruses in the nonvector but viral DNA can be detected in the vector hemolymph $3 \mathrm{~h}$ after the beginning of virus acquisition, and (iii) detect and quantify the virus in the insect compartments involved in virus circulation and persistence. Our results allow us to propose a model explaining the circulation of geminiviruses through their vectors, which is consistent with circulative nonpropagative transmission. 


\section{MATERIALS AND METHODS}

Viruses, leafhoppers, and plants. The transmission tests and insect rearing were conducted in an insect-proof containment chamber at a temperature of $26^{\circ} \mathrm{C}$ and a photoperiod of $17 / 7 \mathrm{~h}$ (day/night). The leafhoppers were reared on millet plants (Pennisetum typhoïdes), which are nonhosts for MSV and Digitaria streak virus (DSV) a member of the genus Mastrevirus. MSV was acquired from maize plants (Zea mays subsp. mays) agroinoculated with R2 clone from the Reunion Island (18). The DSV isolate was imported from the Vanuatu archipelago on plants of its original host species, Digitaria setigera (6), and maintained on this host by vegetative propagation (6). Phylogenetic analysis has established that DSV is closely related to MSV (34). DSV is not transmitted by Cicadulina mbila, a vector of MSV, but is transmitted by the leafhopper, Nesoclutha declivata (19). Maize plants were agroinoculated with cloned DSV as previously described for MSV (18). The isolate of Rice yellow mottle virus (RYMV), a member of the genus Sobemovirus, is from Burkina Faso and was shown to be highly pathogenic on rice plants (25). RYMV is transmitted noncirculatively by coleopterous insects (2). MSV and DSV transmission tests were conducted on maize plants of cv. Golden Cross Bantam (Pioneer, France). Other transmission tests were conducted with DSV on plants of Digitaria setigera, originating from Vanuatu. The RYMV tests were done on rice plants of the variety IR64 (Oryza sativa subsp. indica), which is very susceptible to RYMV, and on which $C$. mbila is able to survive. The transmission tests were carried out with 10 female insects per plant with an AAP and inoculation access feeding period of 3 days each. Transmission was assessed based upon symptom development observed 8 to 10 days after inoculation.

The selection of a $C$. mbila population in which all individuals would be able to transmit MSV was achieved by six generations of brother-sister crossbreeding with leafhoppers originating from the Reunion Island, and which tested positive for MSV transmission at each generation $(30,35,36)$. The transmission efficiency of this population was subsequently monitored at each new generation by individual transmission tests. The $C$. chinaï population used as a negative control for MSV transmission originated from Egypt.

MSV and DSV particles were purified according to the protocols of Larsen and Duffus (20) and Dollet et al. (6), respectively. The integrity of viral particles was verified by transmission electron microscopy (TEM). The serological testing was done by double-antibody sandwich, enzyme-linked immunosorbent assay, according to Peterschmitt et al. (27) for MSV and DSV, and according to Ioannidou et al. (17) for RYMV.

Artificial feeding and microinjection in the hemolymph. The feeding system, based on double-membrane Parafilm (5), was modified in order to obtain a feed under pressure with the help of a syringe. Feeding was only possible with the use of this mechanism, which somehow mimics the positive pressure of the phloem. The feeding solution was composed of $20 \%$ sucrose, $0.02 \%$ neutral red dye (Kuhlmann, France), and $0.1 \mathrm{mg} / \mathrm{ml}$ of purified virus or crude extract from diseased plants diluted (1:10) with extraction buffer (30). Red color was used as a phototactic attractant and to monitor leafhopper feeding. The integrity of viral particles in the feeding solution was verified after $6 \mathrm{~h}$ of AAP by TEM, following a $2 \%$ uranyl acetate staining.

The 1:10 dilution of crude extract of virus-infected plants or the $0.1 \mathrm{mg} / \mathrm{ml}$ of purified virus was injected into the hemolymph with the help of microcapillaries (30). The volume injected could not be accurately measured due to losses during the injection process, but was approximately $1 \mu \mathrm{l}$.

DNA extraction and PCR analysis in whole and dissected insects. Whole insects or insect components (gut, head, and hemolymph) were always tested in groups of 10 . Insects were dissected under a stereomicroscope with the aid of forceps. To avoid a contamination of the hemolymph by the alimentary bolus, the hemolymph was dissolved in $10 \mu \mathrm{l}$ of sterile water brought into contact with a tear made on the ventral side of the abdominal cuticle. The head containing stylets, salivary glands, and the anterior portion of the digestive system was cut off. Finally, the intestinal tract, including midgut, Malpighian tubules, and hindgut, was dissected. Total DNA extraction was carried out by grinding insect material in liquid nitrogen and using the DNA extraction DNeasy Tissue kit (Qiagen, Germany). DNA from virus-infected plants was used as positive control and was extracted with the DNeasy Plant kit (Qiagen, Germany) from $0.1 \mathrm{~g}$ of leaf material. DNA was eluted in $100 \mu \mathrm{l}$ of sterile water. DNA samples of $2.5 \mu \mathrm{l}$ were used for PCR assays in a total reaction volume of $25 \mu \mathrm{l}$. For each virus, MSV and DSV, two pairs of specific primers were designed to amplify two DNA fragments of approximately $1.4 \mathrm{kbp}$ each, together spanning the complete genome. The fragments amplified for MSV were between positions 862-2267 and 2201-942; positions are given according to the viral strand of clone R2 (AJ224504) (18), and the $\mathrm{G}$ of the start codon of the movement protein gene was taken as position 1. The fragments amplified for DSV were between position 833-2290 and 2165-940; positions are given according to the viral strand of the DSV clone M23022, and position 1 was the same for MSV. The two primer pairs were used separately in each PCR experiment. No amplification product of the expected size was detected when these primers were used with DNA from nonviruliferous insects and healthy plants. PCR amplification consisted of 30 cycles of denaturation $\left(30 \mathrm{~s}\right.$ at $\left.94^{\circ} \mathrm{C}\right)$, annealing $\left(1 \mathrm{~min}\right.$ at $\left.60^{\circ} \mathrm{C}\right)$, and DNA extension $\left(1 \mathrm{~min}\right.$ at $\left.72^{\circ} \mathrm{C}\right)$. Amplified DNA fragments were fractionated in $1 \%$ agarose (Quantum Biotechnologies, Illkirch, France) gels in Tris-borate-EDTA buffer and were detected either with ethidium bromide for amplification products derived from entire insects, heads, or guts, or with GelStar (TEBU, le Perray en Yvelines, France) for those derived from hemolymph. Images of gels were digitally processed with Mitsubishi Video hardware and ClaraVision (Polylabo, France) software.

Quantification of MSV DNA in whole and dissected insects. The LightCycler (Idaho Technology, Idaho Falls, ID) was used for the real-time quantitative PCR procedure. The quantification was carried out on DNA extracts that were previously tested by conventional PCR. DNA amplifications were done with the LC FastStart DNA Master SYBR Green kit (Roche Diagnostics, France), with $1 \mu \mathrm{M}$ of each MSV-specific primers amplifying a region between positions $1621-2252,4 \mathrm{mM} \mathrm{MgCl}_{2}$, and $2 \mu \mathrm{l}$ of template DNA in a total reaction volume of $20 \mu \mathrm{l}$. PCR amplification consisted of an initial 8-min denaturation step at $95^{\circ} \mathrm{C}$ followed by 45 cycles of $10 \mathrm{~s}$ at $95^{\circ} \mathrm{C}, 5 \mathrm{~s}$ at $60^{\circ} \mathrm{C}$, and $30 \mathrm{~s}$ at $72^{\circ} \mathrm{C}$. At each PCR cycle, the amount of specific product was monitored by the double-stranded DNA binding dye SYBR Green I. Each quantitative PCR product was analyzed on an agarose gel to verify that the expected 632-bp fragment was the only amplification product being detected by the LightCycler. No amplification product of the expected size was detected when these primers were used with DNA from nonviruliferous insects and healthy plants. For removing any nonspecific product signal from the amplification curve, the fluorescent signal was acquired at $78^{\circ} \mathrm{C}$ after every PCR cycle. The assessment of the number of MSV DNA copies was based on a standard amplification curve, obtained with a serial dilution of the most concentrated viral DNA sample from each test. It is assumed that the last dilution for which fluorescence can be detected corresponds to 10 copies of viral DNA (29). The sets of insects that were tested by quantitative PCR were tested once, and each DNA extract was tested twice in each test. The number of DNA copies given in the results concerning the accumulation and persistence kinetics of MSV are the number of MSV DNA copies assessed in the PCR reaction volumes. This number has to be multiplied by $50(2 \mu \mathrm{l}$ of DNA extract used as 
template out of a total of $100 \mu \mathrm{l}$ ) and divided by 10 (test groups of 10 insects) to deduce the average number of MSV DNA copies per insect.

Sustained feeding on MSV-infected plants. Insects were maintained for 13 days on maize plants infected with MSV following agroinoculation. For each sampling date during this AAP, a sample of 10 insects was collected and frozen at $-80^{\circ} \mathrm{C}$. The frozen samples were simultaneously tested by PCR after the last sampling. This experiment was carried out with one set of insects tested by conventional PCR with the three distinct pairs of MSVspecific primers and once with quantitative PCR.

Persistence of the virus in whole and dissected insects. After a 3-day AAP on MSV-infected plants, the insects were transferred to millet plants. The insects were sampled between 0 and 26 days after AAP. For every sampling, 10 females were harvested and frozen at $-80^{\circ} \mathrm{C}$. The frozen samples were simultaneously tested by PCR after the last sampling. The same experiment was carried out, except that the hemolymph, the head, and the intestinal tract were tested separately. These two types of experiments were each carried out with three distinct sets of insects. The first two sets were tested by conventional PCR with two distinct primer pairs (862-2267, 2201-942), whereas the third set of insects was tested by conventional PCR with the three MSV-specific primer pairs and once by quantitative PCR. In the case of DSV, the experiment was carried out only on dissected insects (one set of insects only) tested by conventional PCR with the two DSV-specific primer pairs.

Dynamics of virus flow across the gut wall. The time required for MSV to reach the hemolymph of C. mbila, after the start of an AAP, was assessed by testing the leafhopper every hour during a 3-h AAP on virus-infected plants and subsequently after their transfer on millet plants. To enhance feeding during the AAPs, the insects were subjected to a preliminary 1-h fasting period. Each sample consisted of 10 individuals that, upon collection, were immediately immobilized by placing them for $10 \mathrm{~min}$ at $4^{\circ} \mathrm{C}$ and subsequently dissected as described previously. The hemolymph and the guts of 10 female insects were recovered and stored at $-80^{\circ} \mathrm{C}$ for simultaneous testing after the last sampling. This experiment was carried out on three distinct sets of insects; two sets were tested by conventional PCR with two primer pairs (8622267, 2201-942), whereas the other set of insects was tested by conventional PCR with the three MSV-specific primer pairs.

\section{RESULTS}

Transmission specificity tests with different virus-vector combinations. A series of biological tests (Table 1) was carried out with our populations of leafhoppers and viral isolates in order to confirm previously obtained results $(21,30,36)$. C. mbila was capable of transmitting MSV after feeding on infected plants, on virus extracts through membranes, or after viral extract was microinjected into the hemolymph. On the other hand, C. chinaï was unable to transmit the virus after feeding on infected plants or through membranes. For $C$. chinaï, transmission occurred only after injecting the virus into the hemolymph. DSV and RYMV were not transmitted by $C$. mbila or by $C$. chinaï under our experimental conditions (Table 1). A transmission trial of DSV, with $C$. mbila or C. chinaï, from maize plants agroinfected with DSV to Digitaria setigera was also unsuccessful. Taken together, these results showed that, as far as transmission was concerned, the results obtained with the biological materials used for this study were similar to those previously reported. Notably, we confirmed that a nonvector species belonging to the genus Cicadulina was able to transmit MSV when virus access across the gut wall was bypassed.

MSV accumulation in whole insects maintained on virusinfected plants. To test if the difference between $C$. mbila and $C$. chinaï, concerning transmission of MSV, could be attributed to inefficient acquisition of the virus by $C$. chinaï, individuals of both species were tested for the presence of MSV during a sustained feeding period on infected plants. Using the primer pair 1621-2252, MSV was detected by PCR in vector and nonvector insects collected during the whole testing phase, and no difference between the two species regarding MSV acquisition was detected (Fig. 1A). Similar results were obtained with the other two pairs of MSV-specific primers (data not shown). The same samples were further tested with real-time quantitative PCR. The viral amount for $C$. mbila was estimated at $0.96 \times 10^{6}$ copies of viral DNA 13 days after the start of acquisition, whereas for $C$. chinaï, the maximum was $0.2 \times 10^{6}$ copies (Fig. 1B). This indicates a difference in virus accumulation, but seemingly not a difference of virus accessibility because during the first $6 \mathrm{~h}$ of AAP, the viral accumulation rate was similar between the two species. For $C$. chinaï, the number of viral DNA copies very quickly attained a plateau of $0.2 \times 10^{6}$ copies, whereas in the case of $C$. mbila, virus accumulation continued up to the end of the test. Therefore, it appears that the vector species continued to accumulate the virus with the passage of time, whereas the nonvector species quickly attained a saturation level.

MSV persistence in whole insects following a 3-day AAP. In order to further investigate the difference between $C$. mbila and $C$. chinaï regarding MSV accumulation rate, the fate of the acquired virions were assessed for leafhoppers that were separated from their viral source after a 3-day AAP. Using the primer pair 16212252, MSV was detected by PCR in $C$. mbila throughout the testing phase with apparently no reduction of the intensity of the bands corresponding to the specific amplification products (Fig. 2A). However, with $C$. chinaï, the intensity of the bands was

TABLE 1 . Study of the specificity of Maize streak virus (MSV) transmission with Cicadulina mbila and the nonvector species $C$. china ${ }^{\text {a }}$

\begin{tabular}{|c|c|c|c|c|c|}
\hline \multirow[b]{2}{*}{ Species } & \multirow[b]{2}{*}{ Transmission $^{\mathrm{b}}$} & \multirow{2}{*}{$\begin{array}{c}\text { Maize agroinoculated } \\
\text { with MSV-R2c }\end{array}$} & \multicolumn{2}{|c|}{ DSV on Digitaria setigerac } & \multirow{2}{*}{$\begin{array}{c}\text { RYMV } \\
\text { on rice }^{c} \\
\text { Rice }\end{array}$} \\
\hline & & & Maize & Digitaria setigera & \\
\hline \multirow[t]{4}{*}{ C. mbila } & Natural & Yes & No & No & No \\
\hline & Artificial feeding of purified virus & Yes $(10 / 10)$ & No $(0 / 4)$ & No $(0 / 4)$ & No $(0 / 4)$ \\
\hline & Microinjection of crude extract of infected plant into the hemolymph & Yes $(4 / 4)$ & No $(0 / 4)$ & No $(0 / 4)$ & No $(0 / 4)$ \\
\hline & Microinjection of purified virus into the hemolymph & Yes $(4 / 4)$ & No $(0 / 4)$ & No $(0 / 4)$ & No $(0 / 4)$ \\
\hline \multirow[t]{4}{*}{ C. chinaï } & Natural & No & No & No & No \\
\hline & Artificial feeding of purified virus & No $(0 / 20)$ & No $(0 / 4)$ & No $(0 / 4)$ & No $(0 / 4)$ \\
\hline & Microinjection of crude extract of infected plant into the hemolymph & Yes $(1 / 4)$ & No $(0 / 4)$ & No $(0 / 4)$ & No $(0 / 4)$ \\
\hline & Microinjection of purified virus into the hemolymph & Yes $(2 / 4)$ & No $(0 / 4)$ & No $(0 / 4)$ & No $(0 / 4)$ \\
\hline
\end{tabular}

a Viruses that are not transmitted by the leafhoppers of the genus Cicadulina, Digitaria streak virus (DSV) and Rice yellow mottle virus (RYMV), were also tested. Yes indicates successful transmission assessed by virus-induced symptoms. No indicates no transmission according to lack of typical symptoms and negative reaction by enzyme-linked immunosorbent assay tests. Ratios in brackets indicate the number of plants exhibiting virus-induced symptoms per number of test plants. Each test plant was tested with 10 insects.

$\mathrm{b}$ Transmission test of 100 insects per test plant. Acquisition and inoculation access period of 3 days.

${ }^{c}$ Virus source/test plant. 
progressively reduced, and no product of the expected size was detected beyond 14 days after termination of AAP (day 14; Fig. 2A). Similar results were obtained with the other two pairs of MSV-specific primers (data not shown). These results demonstrate that viral accumulation in C. mbila and in C. chinaï are different. Classical PCR could not determine if the amounts of virus were equivalent for both species at day 0 , or whether the amount of virus in $C$. mbila was actually stable over time. Therefore, realtime quantitative PCR assays were conducted on the same samples (Fig. 2B). On termination of AAP, the amount of virus in C. mbila was 26 times greater than that in $C$. chinaï. In the 5 days following removal from infected plants, the amount of virus detected in C. mbila and C. chinaï was reduced by six times and by 190 times, respectively. Thereafter, the viral amount remained in the vicinity of $3 \times 10^{4}$ copies in the vector insects, but was below the accuracy threshold of quantitative PCR tests (approximately 10 copies; 29) in the nonvector insects from day 17 onward. The reduction over time in the viral titer in vector insects is consistent with MSV transmission of the nonpropagative type. The difference between the two species regarding the amount of virus at day 0 and the slope difference of the downward curves for the viral titer in the insects confirmed that there is a difference in the virus retention characteristics between $C$. mbila and $C$. chinaï.

MSV persistence in the gut, hemolymph, and head. The difference in virus retention was further analyzed based on a modification of the previous experiment; the three compartments that usually play a role in circulative transmission were separately tested (Fig. 3). Using the primer pair 2201-942, MSV was detected in the gut, hemolymph, and head of C. mbila throughout the testing period. Similar results were obtained with the other primer
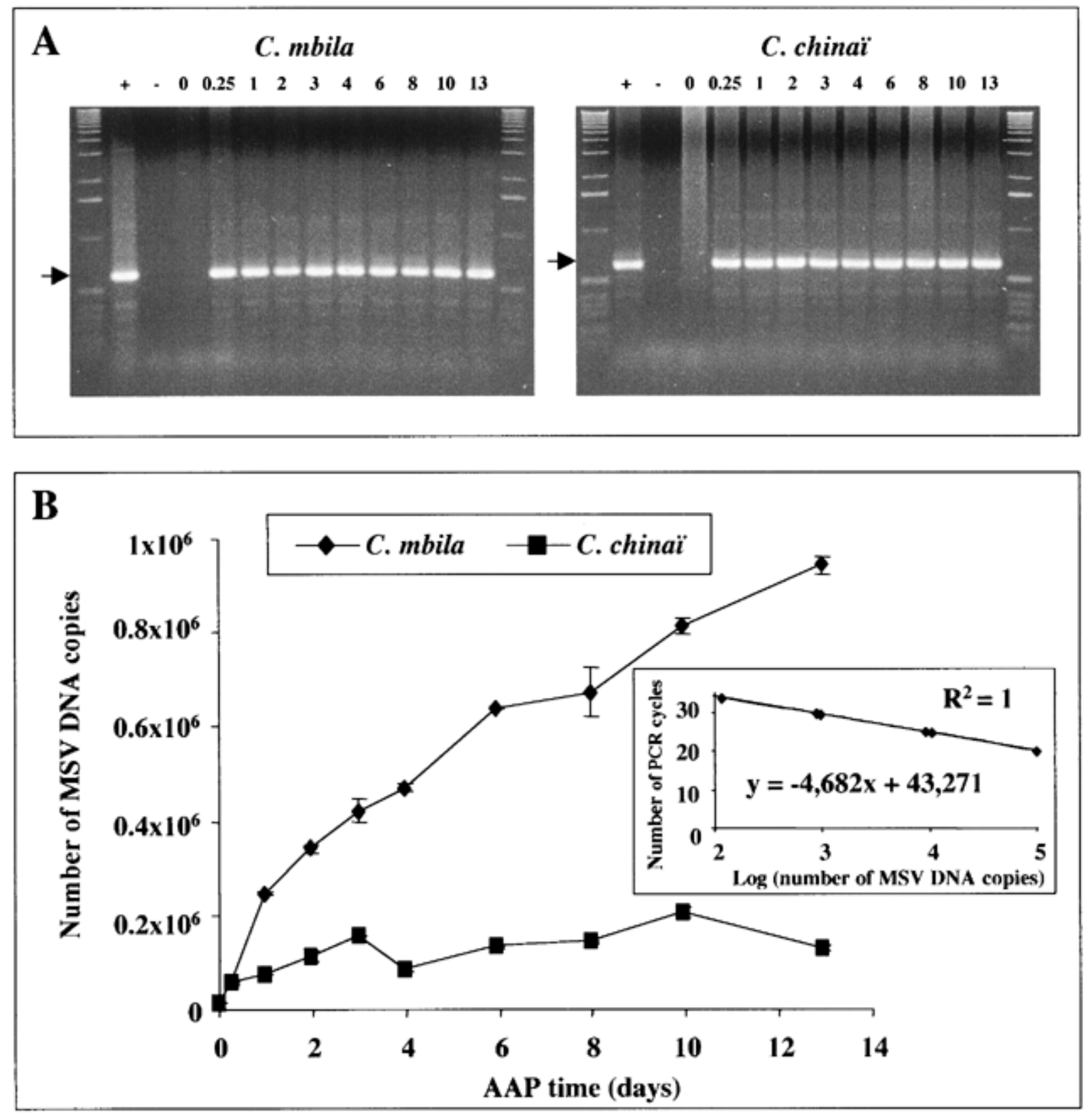

Fig. 1. Accumulation kinetics of Maize streak virus (MSV) in leafhoppers of the vector species Cicadulina mbila and of the nonvector species $C$. chinaï during a sustained feeding on maize plants infected with MSV after agroinoculation. Ten whole insects, collected and frozen at each sampling time, were simultaneously tested by polymerase chain reaction (PCR) after the last sampling with the MSV-specific primer pair 1621-2252. A, PCR products were fractionated in $1 \%$ agarose gels. Arrows indicate the 632-bp MSV DNA fragment. $+=$ DNA extracted from an MSV-infected maize plant (positive control), and $-=$ no DNA template (negative control). Other lanes correspond to batches of 10 insects that were given 0 to 13 day acquisition access feeding periods (AAPs). B, Quantitative PCR detection using the same insect samples as for A. Insert of standard curve showing the equation and fit of the line. Bars = standard error of the mean of two replicates. 
pairs (data not shown). The detection of the virus in the head and in the hemolymph during the entire testing period points toward a continuous movement of viral particles through the three compartments and a constant flow of virions toward the hemolymph and the head. In $C$. chinaï, the intensity of the bands corresponding to specific PCR products obtained with the gut samples gradually decreased from day 0 until day 7 , and were not detected from day 10 onward. With the exception of day 0 , the virus was not detected in the hemolymph or the head of $C$. chinaï. These results are consistent with nontransmission, and show that the gut wall acts as a specific barrier to the flow of MSV particles. Moreover, the restriction of the virus to the gut of $C$. chinaï is consistent with inefficient virus accumulation and retention (Figs. 2 and 3).
DSV persistence in the gut, hemolymph, and head. To further confirm that the gut is an important barrier in the mastrevirus-leafhopper relationship, the previous experiment was repeated with incompatible mastrevirus-leafhopper combinations. DSV is closely related to MSV but is experimentally nontransmissible by $C$. mbila and $C$. chinaï. DSV was detected in the intestinal tract of both $C$. mbila and $C$. chinaï throughout the testing period with the primer pair 833-2290 (Fig. 4). Nevertheless, the concentration of the amplification product decreased over time following the termination of the 3-day AAP. This tendency was more striking in $C$. chinaï. DSV was not detected in the head and hemolymph of $C$. mbila or $C$. chinaï, except at day 0 when it was detected in the head and hemolymph of $C$. mbila, and at day 0
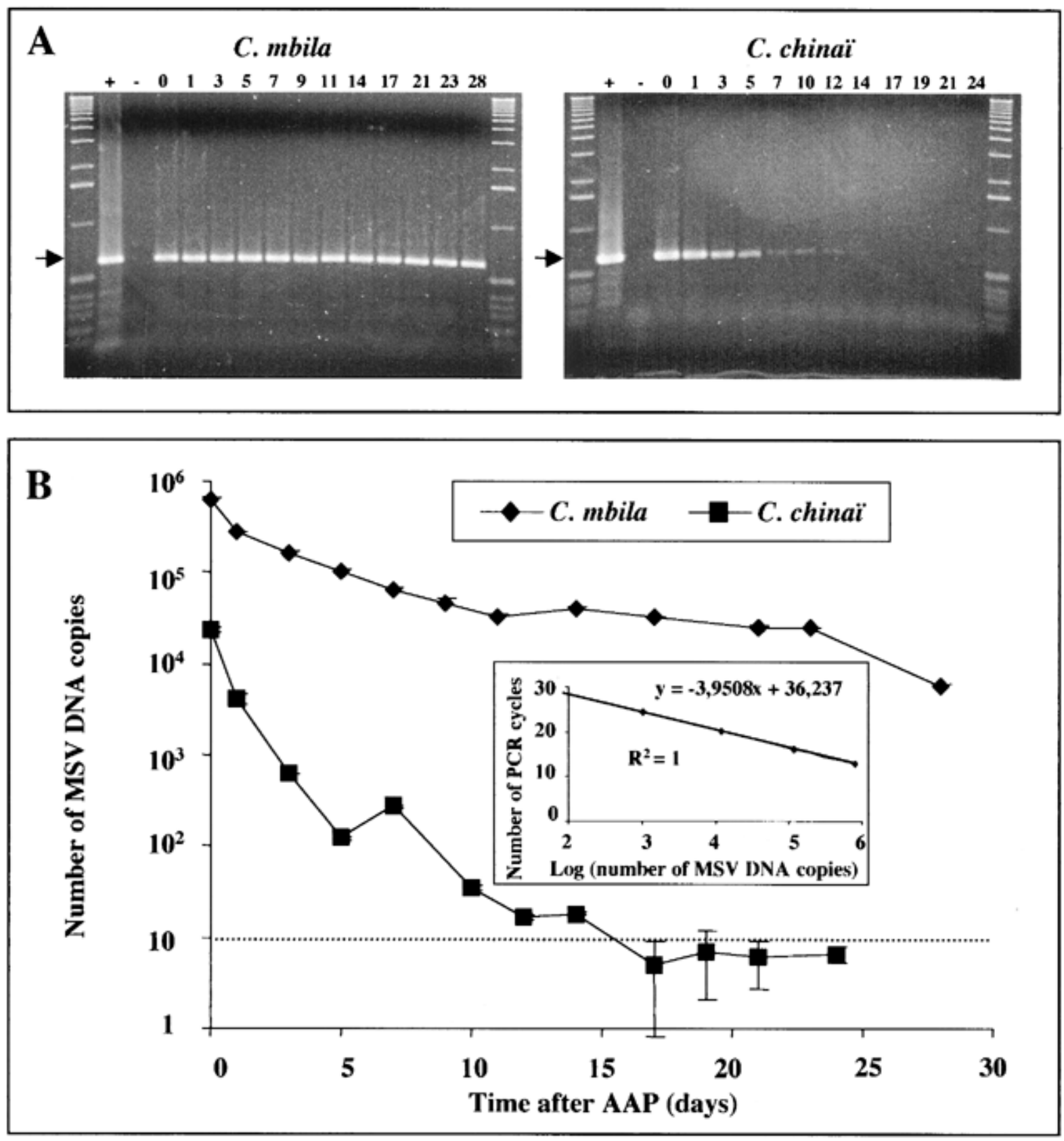

Fig. 2. Persistence kinetics of Maize streak virus (MSV) in leafhoppers of the vector species Cicadulina mbila and the nonvector species $C$. chinaï maintained on nonhost millet plants after a 3-day acquisition access feeding period (AAP) on MSV-infected maize plants. Ten whole insects, collected and frozen at each sampling time after the end of the AAP, were simultaneously tested by polymerase chain reaction (PCR) after the last sampling with the MSV-specific primer pair 1621-2252. A, PCR products were fractionated in 1\% agarose gels. Arrows indicate the 632-bp MSV DNA fragment. + = DNA extracted from an MSVinfected maize plant (positive control), and $-=$ no DNA template (negative control). Other lanes correspond to batches of 10 insects collected between 0 and 28 days after AAP. B, Quantitative PCR detection using the same insect samples as for A. The detection threshold is indicated by the dotted line. Insert of standard curve showing the equation and fit of the line. Bars = standard error of the mean of two replicates. 
and day 1 when it was detected in the hemolymph of $C$. chinaï. Similar results were obtained with the other DSV-specific primer pair (data not shown). The restriction of DSV within the gut of the two nonvector species confirmed that the gut is an important barrier to the circulative transmission of mastreviruses by leafhoppers.

MSV flow-rate across the gut wall. According to the four virus-vector combinations studied, the continuous virus flow across the gut wall was only observed in the case of the combination for which transmission was possible. This suggests that it was a specific phenomenon that can rapidly occur after the vector insect was given access to a viral source. In order to demonstrate this, the AAP was reduced from 3 days to $3 \mathrm{~h}$, and leafhoppers were collected for testing every hour during and after the 3-h AAP
(Fig. 5). Using the primer pair 2201-942, MSV was detected in the guts of $C$. mbila and $C$. chinai in all the samples collected after the beginning of the AAP, confirming acquisition of the virus. MSV was not detected in any hemolymph sample of $C$. chinaï, whereas it was detected in the hemolymph samples of $C$. mbila collected at the end of the 3-h AAP and after. The intensity of the amplification signal gradually increased from the first detection until the end of the test. Similar results were obtained with the other two MSV-specific primer pairs (data not shown). The short time required by the virus to cross the gut wall suggests an active phenomenon.

Quantitative PCR-based monitoring of MSV amount in the three compartments of the vector $\boldsymbol{C}$. mbila. The fact that MSV enters into the insect vector through the gut and exits through

\section{C. mbila}

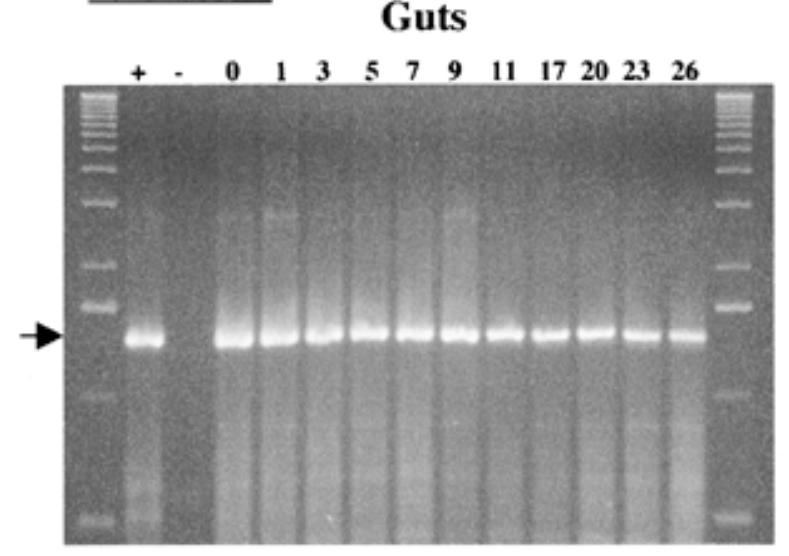

Hemolymphs

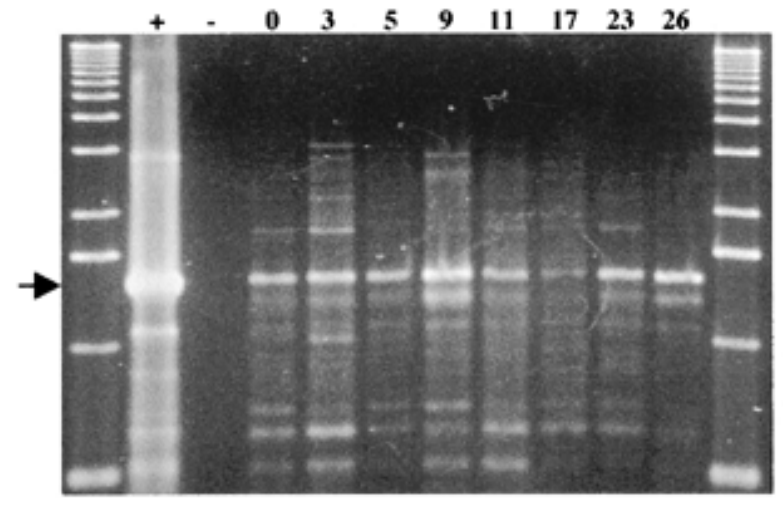

Heads

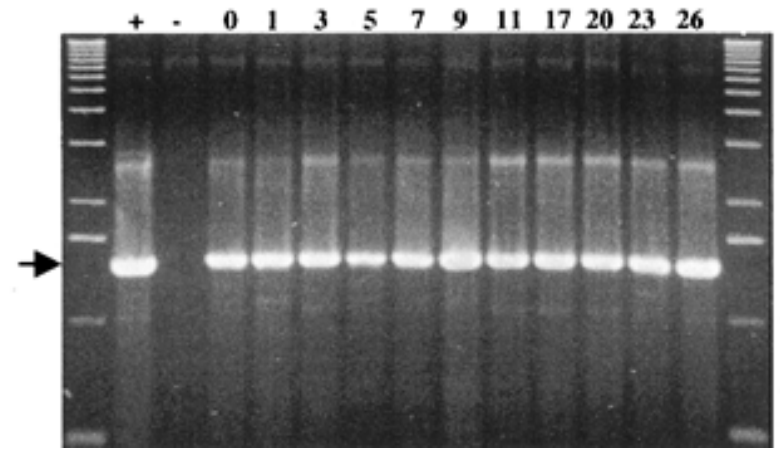

C. chinaï

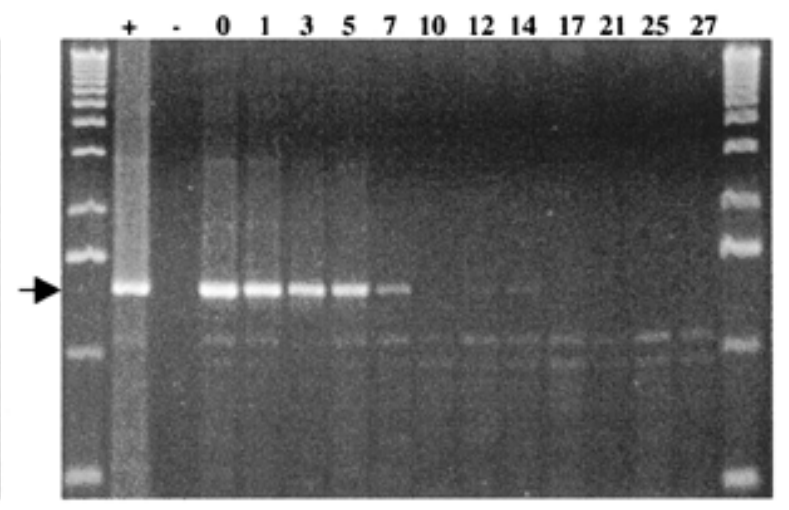

Hemolymphs

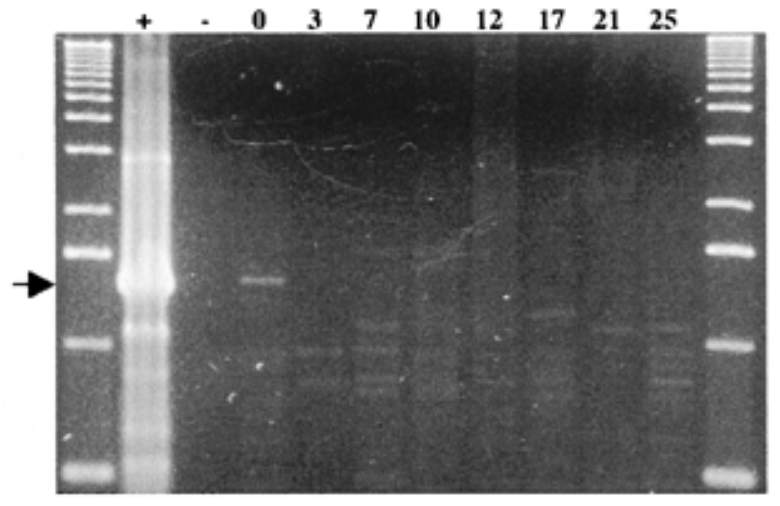

Heads

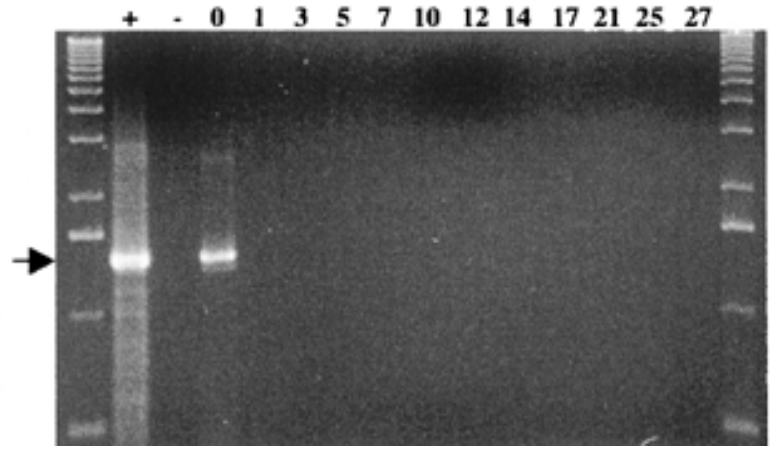

Fig. 3. Persistence kinetics of Maize streak virus (MSV) in leafhoppers of the vector species Cicadulina mbila and the nonvector species $C$. chinaï maintained on nonhost millet plants following a 3-day acquisition access feeding period (AAP) on MSV-infected maize plants. At each sampling time after the end of the AAP, the guts, hemolymphs, and heads of 10 insects were dissected and frozen. The frozen samples were simultaneously tested by polymerase chain reaction (PCR) after the last sampling with the MSV-specific primer pair 2201-942. PCR products were fractionated in 1\% agarose gels. The gels corresponding to hemolymph samples were stained with GelStar, the other gels with ethidium bromide. Arrows indicate the 1.4-kbp MSV DNA fragment. $+=$ DNA extraction from an MSV-infected maize plant (positive control), and $-=$ no DNA template (negative control). Other lanes correspond to guts, hemolymphs, and heads of 10 insects collected between 0 and 27 days after AAP. 
salivary glands implies a viral flow through the insect body. The previous experiment showed that this flow was very rapidly detected in C. mbila, based upon the presence of virus in the hemolymph samples collected $3 \mathrm{~h}$ after the beginning of the 3-h AAP. To further analyze this flow, a set of insect extracts from the three compartments involved in circulative transmission and previously shown to persistently contain virus (Fig. 3) were tested again with real-time quantitative PCR (Fig. 6). Interestingly, the number of MSV DNA copies detected in the gut and in the hemolymph decreased by about $90 \%$ during the 26 days following the 3-day AAP, whereas the number of copies detected in the heads was stable. The decrease was more noticeable during the first 7 days. During the whole testing period, the number of copies detected in the gut was the highest, ranging between $9.3 \times 10^{4}$ and $0.6 \times 10^{4}$, whereas the number of copies detected in the hemolymph was the lowest, decreasing from $7 \times 10^{2}$ to $10^{2}$ over the sampling period. The number of copies detected in the heads was maintained around $0.3 \times 10^{4}$ copies.

\section{DISCUSSION}

PCR as a study tool for viral transmission. Our PCR procedure had the required accuracy for detecting geminiviruses in individual insects or individual dissected organs (data not shown), which is consistent with previous results $(10,24,32)$. However, groups of 10 insects were tested together to eliminate the interindividual variability. Bands of unexpected size were detected on several gels (Figs. 3 and 4). Based on the consistency of the PCR

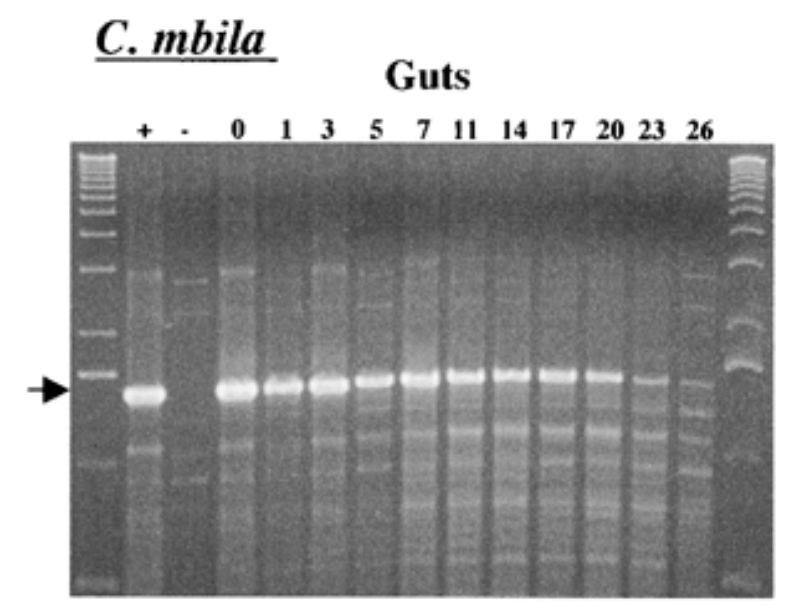

\section{C. chinaï}

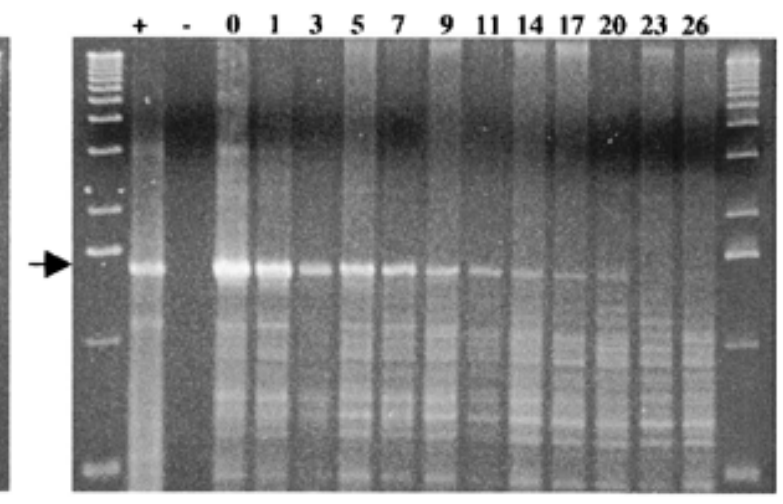

Hemolymphs

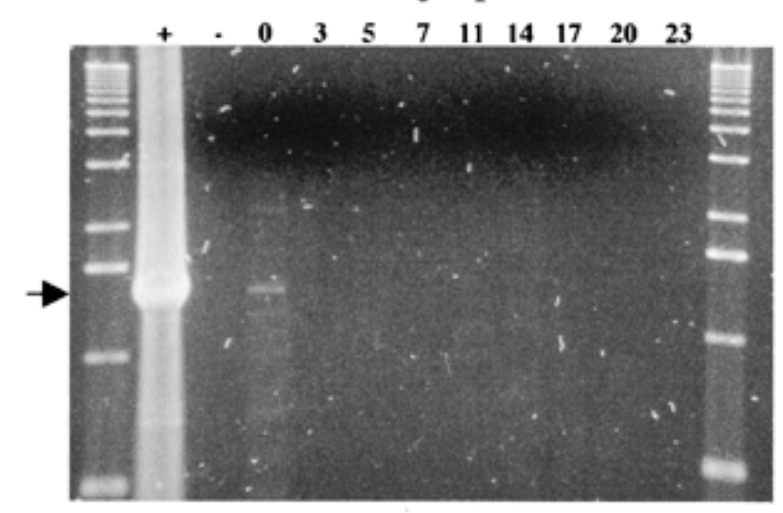

Hemolymphs

Heads

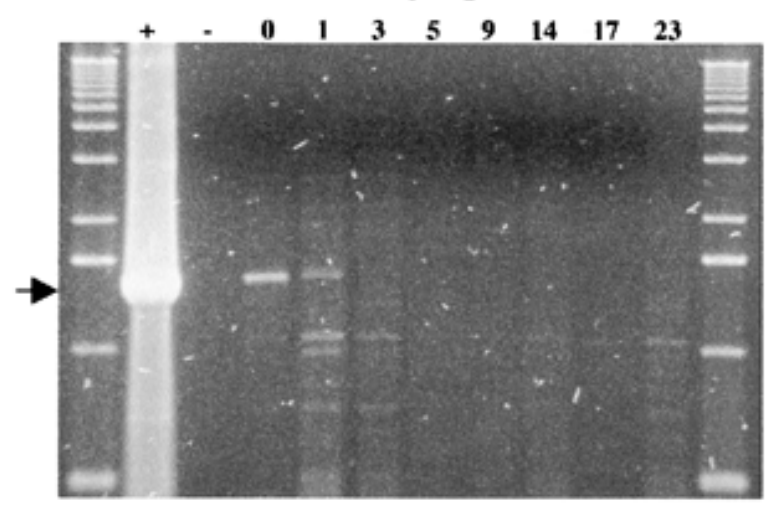

\section{Heads}
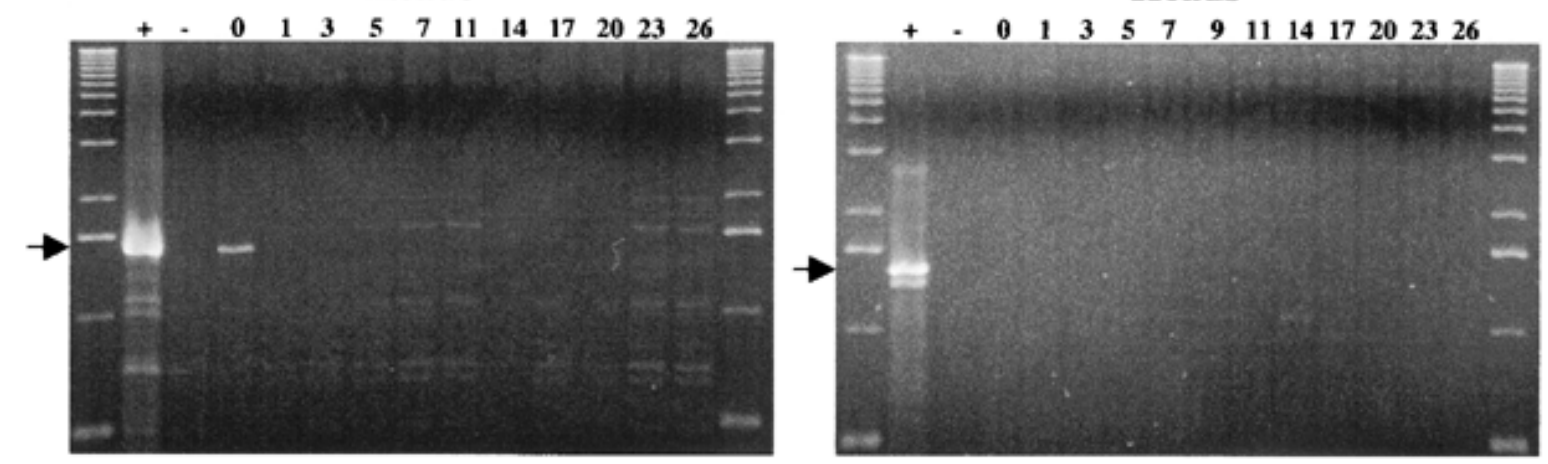

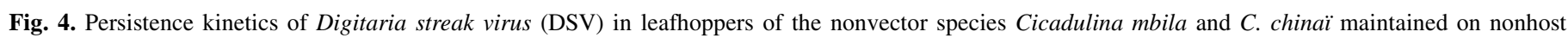

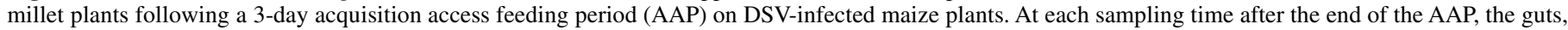

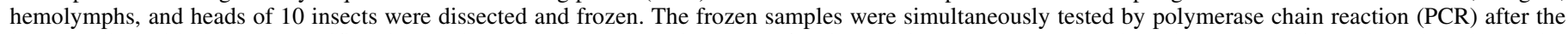

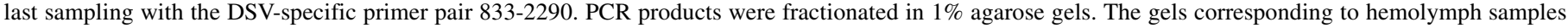

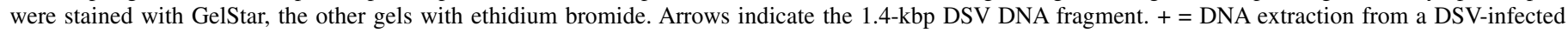

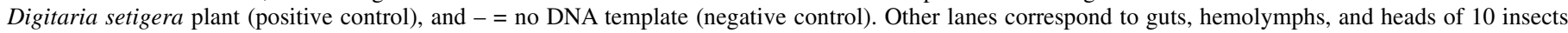
collected between 0 and 26 days after AAP. 
results generated with two or three distinct pairs of primers, these bands were thought to correspond to nonspecific detection. It has to be noted that GelStar staining, used with hemolymph samples for its enhanced sensitivity for DNA detection, resulted in increased detection of DNA fragments of unexpected size (Fig. 4). Similar results were obtained with the two pairs of primers designed to amplify together the whole genome, suggesting that the virus DNA detected by PCR was mainly circular undegraded viral DNA. The comparison of vector and nonvector insects, regarding virus occurrence in the three compartments involved in the circulative transmission, provided information on transmission barriers $(1,32)$. This comparison can be monitored over time to assess the persistence of the virus within the insect. With real-time quantitative PCR, which provides an estimation of the number of viral DNA copies, it was possible to assess the amount of virus in each compartment, providing data from which viral flow and viral persistence may be deduced. While testing the same samples by conventional PCR and by real-time quantitative PCR, the intensity of detection signals in the conventional PCR was proportional only under the saturation threshold of viral DNA copies (Fig. 1 versus Fig. 2). The use of real-time quantitative PCR in other vector-virus combinations may further improve the comprehension of the transmission mechanisms of circulative viruses and their kinetics.

The gut wall acting as a physical barrier for geminiviruses. The following three combinations, representing a leafhopper species and a nontransmitted geminivirus, were analyzed: $C$. chinaï-MSV, C. mbila-DSV, and C. chinaï-DSV. In all three cases, the presence of the virus was restricted to the gut. This indicated that the gut acts as a physical barrier for the transmission. The occasional detection of virus in the hemolymph of nonvector species was apparently not attributable to experimental contamination, because it always appeared in the first insect sample collected after the end of the AAP. This suggests that the gut wall is not totally impass- able, but that the virus amount detected in hemolymph samples does not suffice for attaining the level required for MSV transmission. Such a level is apparently attained for MSV by injecting crude extract of virus-infected plants or purified virus into the hemolymph (Table 1). The requirement of minimal viral doses in some compartments of the insect body for successful transmission needs to be further investigated. Alternatively, the virus detected in hemolymph samples of nonvectors may correspond to naked DNA. This would remain consistent with nontransmission because the integrity of geminivirus particles appears to be required for successful transmission (15). Virus detection in the head of nonvector species on termination of AAP is possibly a phenomenon related to the presence of virions in the alimentary bolus found in the anterior digestive system.

The restriction of MSV and DSV in the gut of nonvector species is coupled with a relatively quick reduction of the amount of virus over time. The reduction rate appears to be slower for DSV compared with MSV. This could be the result of a different susceptibility of the particles to the biochemical and physical conditions existing within the gut. Indeed, unlike DSV, the integrity of MSV virions is not well maintained in virus extracts from infected plants (data not shown; 15). This emphasizes that the preservation of MSV virions in its vector $C$. mbila needs a peculiar mechanism that makes MSV persistence and transmission possible. It could involve an internalization of the virions by receptor-mediated endocytosis, similar to what has been demonstrated for the Luteoviridae-aphid model (12).

MSV crosses the gut wall in less than $3 \mathrm{~h}$ after the beginning of AAP. Similar results were obtained with the begomoviruses, TYLCV and SLCV, which were detected by PCR in the hemolymph of B. tabaci 1.5 and $2 \mathrm{~h}$, respectively, after the beginning of the AAP $(10,32)$. The short time required by geminiviruses to cross the gut wall of vector insects argues for the existence of an active mechanism for transmembrane flow via a specific receptor.

\section{C. mbila}

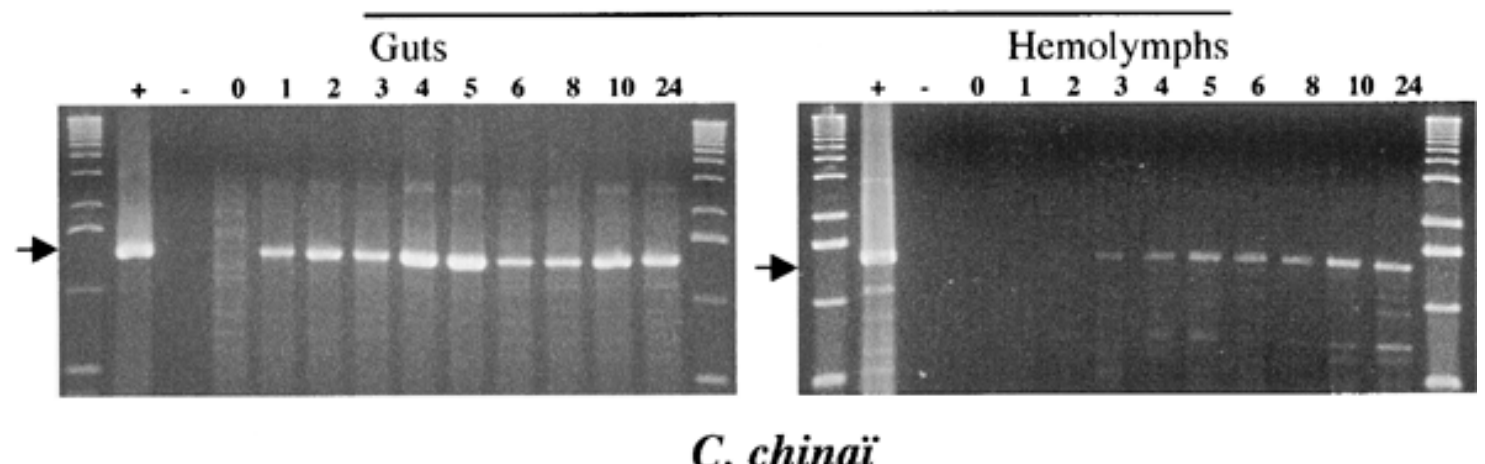

C. chinaï

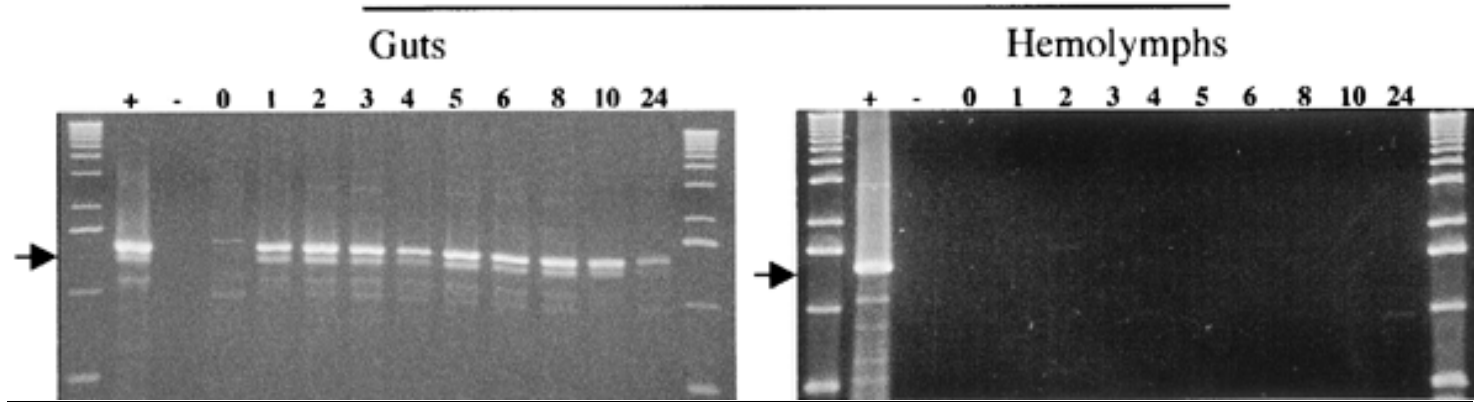

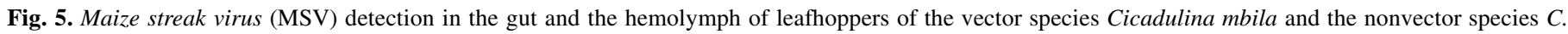

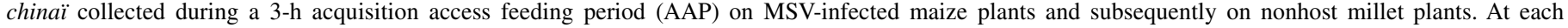

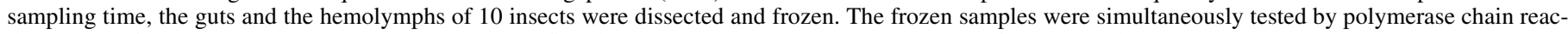

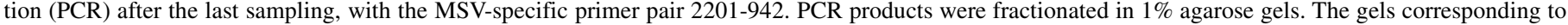

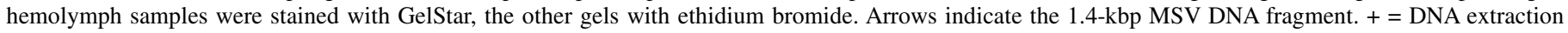

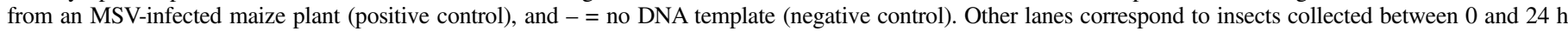
after the beginning of the 3-h AAP. 
Presence of a second level barrier. Although the virus was restricted to the gut in all three combinations for which virus transmission was not possible, there is only one combination, $C$. chinaï-MSV, for which transmission became possible when the gut barrier was bypassed by injection of the virus directly into the hemolymph. Getting a nonvector to transmit virus by injection was also described for an aphid-rhabdovirus combination, Macrosiphum euphorbiae-Strawberry crinkle virus (37). The nontransmission of DSV by $C$. mbila and $C$. chinaï, even after bypassing the gut wall, suggests the presence of a second barrier to the transmission of geminivirus by leafhoppers. This hypothesis was suggested in the studies of Markham et al. (21), in which it was observed that the leafhopper Dalbulus maïdis (DeL. \& W.) was not capable of transmitting MSV, even after being microinjected with virus extracts. This second transmission barrier seems to be related to the flow across salivary glands. However, the ability of the virus to survive in the hemolymph may also be responsible. The persistence and the transmission efficiency of viruses from the family Luteoviridae by aphids, and of TYLCV by B. tabaci, seems to be related to the virus interaction with homologues of GroEL $(7,23,38,39)$. GroEL involvement in the circulative transmission of geminiviruses by leafhoppers needs to be further investigated.

Storage and preservation of viral particles. The gradual increase in the viral amount in C. mbila, during sustained feeding on diseased plants, confirmed that the vector insect is capable of accumulating a significant quantity of MSV particles (Fig. 1; 31). This quantity does not seem to be restricted in the manner that was suggested for TYLCV (41) and SLCV (28) in B. tabaci. In the case of the nonvector insect, $C$. chinaï, this quantity rapidly reaches a saturation level that seems to correspond to an equilibrium of the amount of virus in the intestinal tract, between virus acquisition and virus elimination through the phenomena of nucleoprotein intake, degradation, and intestinal transit. Our results suggest that the difference observed in the viral amount between C. mbila and C. chinaï (Figs. 2 and 3) is accounted for by the portion of particles internalized by the former and stored mainly in the epithelial cells of the intestinal tract, and to a lesser extent in the salivary glands (Fig. 6). The similar MSV accumulation during the first few hours of AAP for C. mbila and for C. chinaï (Fig. 1) suggests that the feeding behavior does not play a major role in the differential virus accumulation between vector species and nonvector species belonging to the genus Cicadulina. Nevertheless, this hypothesis needs to be confirmed with an electrical penetration graph technique. The fact that viral DNA was not detected in C. chinaï beyond 14 days after termination of AAP (Fig. 2) suggests that the virus that was not stored was eliminated within about 2 weeks. Consequently, it can be assumed that the number of viral DNA copies persisting in C. mbila beyond 14 days after AAP (Fig. 2) mainly correspond to the internalized and preserved viral particles. This is consistent with the trend of the curve showing the decrease of the viral DNA copies, with a steeper slope during the first 11 days compared with the slope observed later (Fig. 2).

Dynamic model of circulative nonpropagative transmission of MSV through $\boldsymbol{C}$. mbila. The maintenance of MSV in the head of $C$. mbila during the entire testing phases (Figs. 3 and 6) is consistent with the ability of this vector to transmit the virus for 5 weeks after an AAP of only $3 \mathrm{~h}$ (31). It is supposed that the virus detected in the head is mainly in the salivary glands. The hemolymph, which may have remained in the head after dissection, will not affect the virus concentration because virus concentration in the hemolymph is relatively low. Moreover, based on the absence of virus in the head of nonvectors, it can be supposed that the virus that may remain in the stylets, the cibarium, or the esophagus of vector insects after feeding is insignificant and does not affect the virus concentration in their head. To explain the relatively stable concentration in absence of virus multiplication, it has to be assumed that the virus released by the salivary glands into plants on which viruliferous vectors are feeding is replaced by virus from another compartment, most likely the hemolymph. The fact that it is rather unlikely that the entering flow of virus from the hemolymph would be exactly equal to the flow of virus released by saliva, virus stability in the salivary glands is due to a permanent saturation of a limited storage capacity, corresponding in average to $1.5 \times 10^{4}$ copies of viral DNA per insect. Consequently, the apparently unlimited MSV storage capacity of a vector insect is probably not related to this organ (Fig. 1). Our data showed that the decrease in the number of virus DNA copies detected in the gut and the hemolymph was about $90 \%$ in both compartments during the 26 days of test, which suggests that a similar mechanism may be operating. This decrease is probably the result of viral degradation and viral flow toward the salivary glands. The relatively low number of DNA copies detected in the hemolymph extracts may indicate that this compartment is a transit compartment, which has no storage capacity. Conversely, the gut, in which the highest virus DNA concentration was detected throughout the test, can be considered the major storage compartment. This observation is contrary to what was suggested for the circulative transmission of viruses of the family Luteoviridae and of the genus Nanovirus by aphids, for which hemolymph was considered the main storage compartment for viral

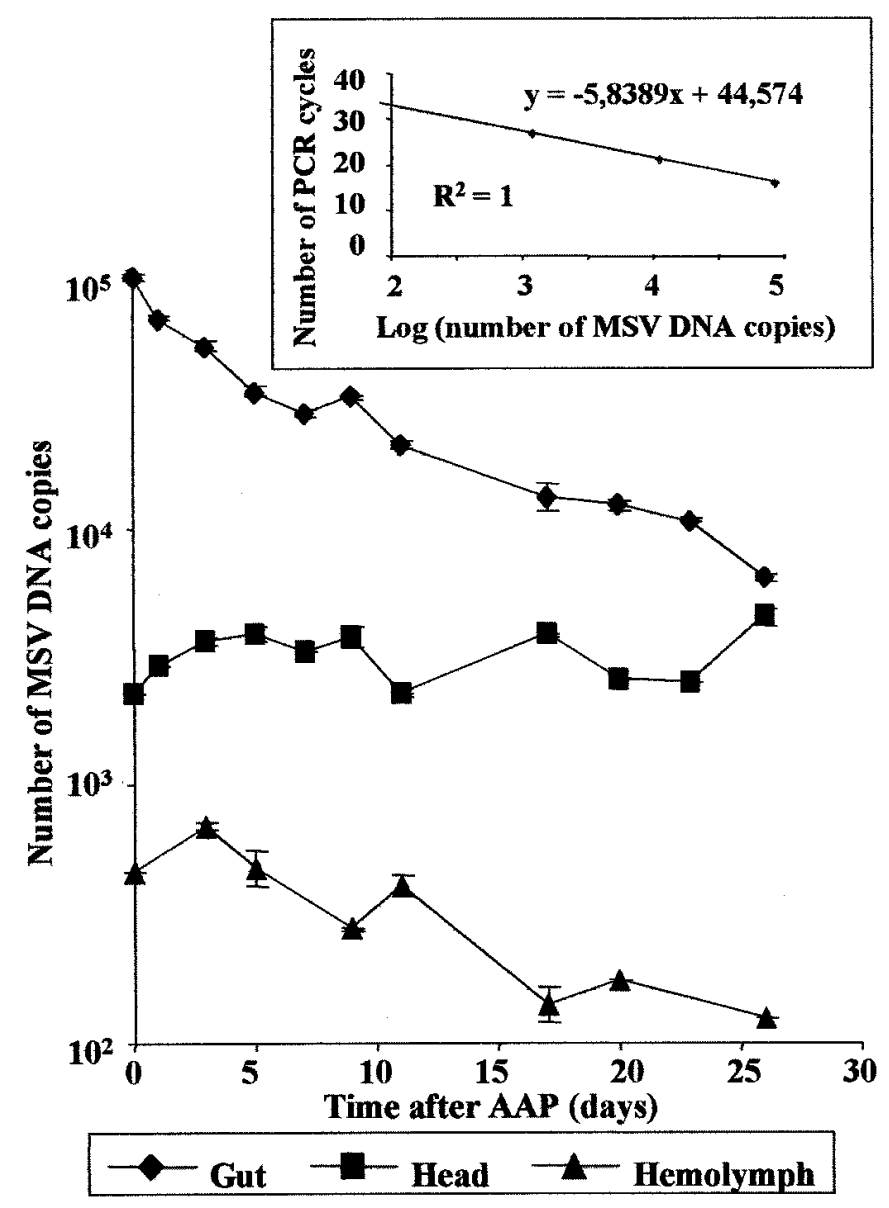

Fig. 6. Persistence kinetics of Maize streak virus (MSV) in leafhoppers of the vector species Cicadulina mbila maintained on nonhost millet plants following a 3-day acquisition access feeding period (AAP) on MSV-infected maize plants. At each sampling time after the end of the AAP, the guts, hemolymphs, and heads of 10 insects were dissected and frozen. The frozen samples were simultaneously tested by quantitative polymerase chain reaction (PCR) after the last sampling with the MSV-specific primer pair 1621-2252. The samples tested by quantitative PCR were previously tested by conventional PCR (Fig. 3). Insert of standard curve showing the equation and fit of the line. Bars $=$ standard error of the mean of two replicates. 
particles $(8,38,39)$. The use of real-time quantitative PCR for the comparison of circulative nonpropagated viruses from different families and genera should confirm this discrepancy.

\section{ACKNOWLEDGMENTS}

Research was conducted during the thesis scholarship program of J. M. Lett, supported by le Ministère Français de la Recherche. We thank D. Fargette (Ird, Fr) for providing the RYMV isolate.

\section{LITERATURE CITED}

1. Atzmon, G., Van Oss, H., and Czosnek, H. 1998. PCR-amplification of tomato yellow leaf curl virus (TYLCV) DNA from squashes of plants and whitefly vectors: Application to the study of TYLCV acquisition and transmission. Eur. J. Plant Pathol. 104:189-194.

2. Bakker, W. 1974. Characterization and ecological aspects of rice yellow mottle virus in Kenya. Ph.D. thesis. Wageningen University, the Netherlands.

3. Boulton, M. I., and Markham, P. G. 1986. The use of squash-blotting to detect plant pathogens in insect vectors. In Developments in Applied Biology 1. Developments and Applications in Virus Testing. R. A. C. Jones and L. Torrance, eds. Assoc. Appl. Biol., Kew, England.

4. Caciagli, P., and Bosco, D. 1997. Quantitation over time of tomato yellow leaf curl geminivirus DNA in its whitefly vector. Phytopathology 87:610-613.

5. Costa, H. S., Henneberry, T. J., and Toscano, N. C. 1997. Effects of antibacterial materials on Bemisia argentifolii (Homoptera: Aleyrodidae) oviposition, growth, survival and sex ratio. J. Econ. Entomol. 90:333339.

6. Dollet, M., Accoto, G. P., Lisa, V., Menissier, J., and Boccardo, G. 1986. A geminivirus, serologically related to maize streak virus, from Digitaria sanguinalis from Vanuatu. J. Gen. Virol. 67:933-937.

7. Filichkin, S. A., Brumfield, S., Filichkin, T. P., and Young, M. J. 1997. In vitro interactions of the aphid endosymbiotic symL chaperonin with barley yellow dwarf virus. J. Virol. 71:569-577.

8. Franz, A., Makkouk, K. M., and Vetten, H. J. 1998. Acquisition, retention and transmission of faba bean necrotic yellows virus by two of its aphid vectors, Aphis craccivora (Koch) and Acyrthosiphon pisum (Harris). J. Phytopathol. 146:347-355.

9. Ghanim, M., and Czosnek, H. 2000. Tomato yellow leaf curl geminivirus (TYLCV-Is) is transmitted among whiteflies (Bemisia tabaci) in a sexrelated manner. J. Virol. 74:4738-4745.

10. Ghanim, M., Morin, S., and Czosnek, H. 2001. Rate of Tomato yellow leaf curl virus translocation in the circulative transmission pathway of its vector, the whitefly Bemisia tabaci. Phytopathology 91:188-196.

11. Ghanim, M., Morin, S., Zeidan, M., and Czosnek, H. 1998. Evidence for transovarial transmission of tomato yellow leaf curl virus by its vector, the whitefly Bemisia tabaci. Virology 240:295-303.

12. Gildow, F. E. 1987. Virus-membrane interactions involved in circulative transmission of luteoviruses by aphids. Adv. Dis. Vector Res. 4:93-120.

13. Gildow, F. E. 1993. Evidence for receptor-mediated endocytosis regulating luteovirus acquisition by aphids. Phytopathology 83:270-277.

14. Gray, S. M., and Banerjee, N. 1999. Mechanisms of arthropod transmission of plant and animal viruses. Microbiol. Mol. Biol. Rev. 63:128-148.

15. Harrison, B. D. 1985. Advances in geminivirus research. Annu. Rev. Phytopathol. 23:55-82.

16. Hunter, W. B., Hiebert, E., Webb, S. E., Tsai, J. H., and Polston, J. E. 1998. Location of geminiviruses in the whitefly Bemisia tabaci (Homoptera: Aleyrodidae). Plant Dis. 82:1147-1151.

17. Ioannidou, D., Lett, J. M., Pinel, A., Assigbetse, K., Brugidou, C., Ghesquière, A., Nicole, M., and Fargette, D. 2000. Responses of Oryza sativa japonica sub-species to infection with Rice yellow mottle virus. Physiol. Mol. Plant Pathol. 57:177-188.

18. Isnard, M., Granier, M., Frutos, R., Reynaud, B., and Peterschmitt, M. 1998. Quasispecies nature of three maize streak virus isolates obtained through different modes of selection from a population used to assess response to infection of maize cultivars. J. Gen. Virol. 79:3091-3099.

19. Julia, J. F., and Dollet, M. 1989. Nesoclutha declivata Homoptera Cicadellidae, vector of Digitaria streak virus (geminivirus) in Vanuatu. J. Phytopathol. 127:42-48.
20. Larsen, R. C., and Duffus, J. E. 1984. A simplified procedure for the purification of curly top virus and the isolation of its monomer and dimer particles. Phytopathology 74:114-118.

21. Markham, P. G., Pinner, S., and Boulton, M. I. 1984. The transmission of MSV by leafhoppers, a new look at host adaptation. Bull. Soc. Entomol. Suisse 57:431-432.

22. Mehta, P., Wyman, J. A., Nakhla, M. K., and Maxwell, D. P. 1994. Transmission of Tomato yellow leaf curl geminivirus by Bemisia tabaci (Homoptera: Aleyrodidae). J. Econ. Entomol. 87:1291-1297.

23. Morin, S., Ghanim, M., Zeidan, M., Czosnek, H., Verbeek, M., and Van den Heuvel, J. F. J. M. 1999. A GroEL homologue from endosymbiotic bacteria of the whitefly Bemisia tabaci is implicated in the circulative transmission of tomato yellow leaf curl virus. Virology 256:75-84.

24. Navot, N., Zeidan, M., Pichersky, E., Zamir, D., and Czosnek, H. 1992. Use of the polymerase chain reaction to amplify tomato yellow leaf curl virus DNA from infected plants and viruliferous whiteflies. Phytopathology 82:1199-1202.

25. NGuessan, P., Pinel, A., Caruana, M. L., Frutos, R., Sy, A., Ghesquière, A., and Fargette, D. 2000. Evidence of the presence of two serotypes of rice yellow mottle sobemovirus in Côte d'Ivoire. Eur. J. Plant Pathol. 106:167-178.

26. Pesic-Van Esbroeck, Z., Harris, K. F., and Duffus, J. E. 1995. Immunocytochemical localization of squash leaf curl virus in squash and the sweet potato whitefly. (Abstr.) Phytopathology 85:1180.

27. Peterschmitt, M., Reynaud, B., Sommermeyer, G., and Baudin, P. 1991. Characterization of MSV isolates using monoclonal and polyclonal antibodies and by transmission to a few hosts. Plant Dis. 75:27-32.

28. Polston, J. E., Al-Musa, A., Perring, T. M., and Dodds, J. A. 1990. Association of the nucleic acid of squash leaf curl geminivirus with the whitefly Bemisia tabaci. Phytopathology 80:850-856.

29. Rasmussen, R., Morrison, T., Herrmann, M., and Wittwer, C. 1998. Quantitative PCR by continuous fluorescence monitoring of a double strand DNA specific binding dye. Biochemica 2:8-11.

30. Reynaud, B. 1988. Transmission des virus de la striure, du stripe et de la mosaïque du maïs par leurs vecteurs, Cicadulina mbila (Naude, 1924) et Peregrinus maïdis (Ashmead, 1890) (Homoptera). Approches biologique, génétique et épidémiologique de la relation vecteur-virusplante. Ph.D. thesis. Université des Sciences et Techniques du Languedoc, France.

31. Reynaud, B., and Peterschmitt, M. 1992. A study of the mode of transmission of MSV by Cicadulina mbila using an enzyme-linked immunosorbent assay. Ann. Appl. Biol. 121:85-94.

32. Rosell, R. C., Torres Jerez, I., and Brown, J. K. 1999. Tracing the geminivirus-whitefly transmission pathway by polymerase chain reaction in whitefly extracts, saliva, hemolymph, and honeydew. Phytopathology 89:239-246.

33. Rubinstein, G., and Czosnek, H. 1997. Long-term association of tomato yellow leaf curl virus with its whitefly vector Bemisia tabaci: Effect on the insect transmission capacity, longevity and fecundity. J. Gen. Virol. 78:2683-2689.

34. Rybicki, E. P. 1994. A phylogenetic and evolutionary justification for three genera of Geminiviridae. Arch. Virol. 139:49-77.

35. Storey, H. H. 1932. The inheritance by an insect vector of the ability to transmit a plant virus. Proc. R. Soc. B 112:46-60.

36. Storey, H. H. 1938. Investigation of the mechanism of the transmission of plant viruses by insect vectors. II. The part played by puncture in transmission. Proc. R. Soc. B 125:455-477.

37. Sylvester, E. S., Richardson, J., and Stenger, D. C. 1987. Use of injected Macrosiphum euphorbiae aphids as surrogate vectors for transfer of strawberry crinkle virus to Nicotiana species. Plant Dis. 71:972-975.

38. Van den Heuvel, J. F. J. M., Bruyère, A., Hogenhout, S. A., ZieglerGraff, V., Brault, V., Verbeek, M., Van der Wilk, F., and Richards, K. 1997. The N-terminal region of the luteovirus readthrough domain determines virus binding to Buchnera GroEL and is essential for virus persistence in the aphid. J. Virol. 71:7258-7265.

39. Van den Heuvel, J. F. J. M., Verbeek, M., and Van der Wilk, F. 1994. Endosymbiotic bacteria associated with circulative transmission of potato leafroll virus by Myzus persicae. J. Gen. Virol. 75:2559-2565.

40. Webb, M. D. 1987. Species recognition in Cicadulina leafhoppers (Hemiptera: Cicadellidae), vectors of pathogens of Gramineae. Bull. Entomol. Res. 77:683-712.

41. Zeidan, M., and Czosnek, H. 1991. Acquisition of tomato yellow leaf curl virus by the whitefly Bemisia tabaci. J. Gen. Virol. 72:2607-2614. 